\title{
Évtizedes késéssel érkező légi támogatás?
}

\section{Az Egyesült Államok Légierejének (USAF) fejlesztése az aszimmetrikus hadmüveleti igények alapján a Light Attack Aircraft beszerzési program során}

\section{Air Support with a Decade Long Delay?}

The Development of USAF Based on Operational Demands through the So-called Light Attack Aircraft Procurement Programme

\section{Absztrakt}

Az Amerikai Egyesült Államok Légiereje (USAF) az utóbbi két évtized aszimmetrikus müveleti igényei alapján egy célzott, kifejezetten az alacsony intenzitású, földi támogató szerepkörre optimalizált beszerzési programot hajtott végre. A program szakaszai, végkifejlete számos problémát felfedett, elsősorban az eredeti elvárások és célkitüzések, valamint az időközben már megváltozott müveleti környezet különbségei okán. Megvizsgálom, hogy az aszimmetrikus képességek túlsúlya továbbra is érvényesül-e, illetve a konvencionális képességek esetleges elötérbe kerülése mennyiben befolyásolta a program sikerességét.

Kulcsszavak: USAF, aszimmetrikus, konvencionális, légierö, légi támogatás, beszerzési program

\section{Abstract}

The United States Air Force (USAF) has conducted a procurement programme specifically for low intense, close air support purposes, based on the asymmetric operational needs

Nemzeti Közszolgálati Egyetem Hadtudományi Doktori Iskola, doktori hallgató - University of Public Service Doctoral School of Military Science, PhD student, e-mail: lestak.tamas@oif.gov.hu 
of the last two decades. The different stages and the outcome of the programme have revealed many issues, mainly due to the significant differences between the original requirements and the current and different operational circumstances. I will examine whether the predominance of these asymmetric skills is still valid or the possible increase of the more conventional abilities had any effect on the success of this particular procurement programme.

Keywords: USAF, asymmetric, conventional, air force, air support, procurement programme

\section{Bevezető}

Tanulmányomban az Amerikai Légierő (United States Air Force, USAF) könnyü támadó, felfegyverzett felderítő-repülőgép rendszerbe állítását célzó programját az aszimmetrikus hadviselés ${ }^{2}$ követelményeinek egy fejlesztési/beszerzési programban megnyilvánuló gyakorlati példájaként vizsgálom. Az elmúlt közel két évtized amerikai terrorellenes hadműveletei nyomán kiemelt szerepet kapott az egyes haderőnemi, sőt fegyvernemi képességek célirányos fejlesztése annak érdekében, hogy az afganisztáni, iraki, líbiai és szír légi hadműveletek során felmerült igényeket ki tudják elégiteni. A fejlesztési forrásokból egyébként is kiemelt arányban részesült légi haderőnem célzottan, kifejezetten az aszimmetrikus feladatok ${ }^{3}$ ellátása érdekében ${ }^{4}$ kívánt új típust rendszeresíteni. A beszerzési program vázlatos ismertetésén keresztül kívánom bemutatni, hogy az eredeti célkitűzés teljesült-e, illetve rávilágítani az aszimmetrikus és konvencionális képességek közötti jelenlegi prioritási különbségekre az amerikai hadvezetésen belül. Megkísérlem eldönteni, hogy közeljövőben a konvencionális képességek a légierő esetében is fokozatosan elsőbbséget kapnak-e a fejlesztési célkitüzések között.

\section{Egy véget nem érö folyamat - egy tipikus 21 . századi beszerzési program története}

Az úgynevezett könnyủ támadó/felfegyverzett felderítő-repülögép beszerzési programja (Light Attack/Armed Reconnaissance programme, LAAR) 2009-ben indult útjára, a légierő hivatalos követelménykiírásakor (2009. július 27-én került kírásra az úgynevezett információkérési felhívás [Request for Information, RFI]), amely egy jövőbeni könnyű támadó, felfegyverzett felderítőgép követelményeit tartalmazta, és 2013-as

\footnotetext{
Krajnc Zoltán: Az aszimmetrikus hadviselés, fenyegetés alapkérdései. Repüléstudományi konferencia, 2008. április 11. Az úgynevezett aszimmetrikus hadviselés pontos fogalmi elhatárolására számos, egymástól kisebb-nagyobb mértékben eltérő verzió létezik a hazai és nemzetközi szakirodalomban. Az egyik hazai definíció szerint: pontosan körvonalazott politikai célok érdekében folytatott, gyakran több szervezet ideológiai, vallási, etnikai közösségén alapuló katonai és nem katonai müveleteket, eljárásokat és módszereket alkalmazó, közvetlen vagy közvetett hatásokra építő és egymás hatásait felerősítő, a biztonság különböző dimenzióinak területét veszélyeztető harcmodor, föként harcászati eljárás, amellyel rákényszeríthetjük akaratunkat az ellenségre.

4 Resperger István - Kiss Álmos Péter - Somkuti Bálint: Aszimmetrikus hadviselés a modern korban. Kis háborúk nagy hatással. Budapest, Zrínyi, 2015. 23.
} 
rendszerbe állítási határidőt szabott meg a pályázók számára). ${ }^{5}$ Ennek elsődleges célja az volt, hogy a múveleti tervezők megfelelő közeli légi támogató platformra tegyenek szert, amellyel az afgán és iraki hadszíntereken eredményesen tudják segíteni a földi csapatok harcát, illetve önállóan is csapást tudjanak mérni az ellenséges erőkre, lehetőleg sokkal költséghatékonyabban, mint az addigi eszközökkel. A 2001-től kezdődő afganisztáni hadmüveletek, valamint a 2003-as iraki hadmüveletek kezdetétől a bombázó müveletek és a közeli légi támogatás esetén ${ }^{6}$ a nagy értékű és - ami még jelentősebb faktor - nagy üzemeltetési költségű típusokkal oldotta meg a légierő

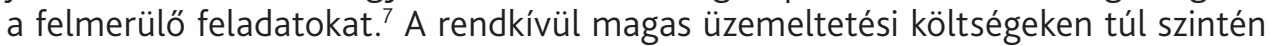
alapvető fontosságú volt az úgynevezett őrjáratozási idő, ${ }^{8}$ amely sokkal rövidebb egy szuperszonikus típus esetén, mint más kisebb, légcsavaros típusoknál. ${ }^{9}$

A fentiek mellett fontos szerepet játszott a program meghirdetésében az amerikai haderő stratégiai elképzeléseinek eltolódása a konvencionális fenyegetések, nevezetesen a Kína jelentette kihívások hatékony leküzdése irányába. A Délkelet-Ázsia felé történő fordulás (Pivot in Southeast Asia) ${ }^{10}$ néven elhíresült stratégia fontos részét képezte a fejlett, lehetőleg 4. vagy 5. generációs repülőgépek alkalmazása egy felkészült, technikailag fejlett ellenféllel szembeni esetleges összecsapás esetén. ${ }^{11}$ Ez pedig azt jelentette, hogy az ekkoriban még több fronton folyó terrorellenes múveletekben nem „pazarolhatták el” a legfejlettebb típusok repült idejét alacsony intenzitású harcokra és más típusokkal esetleg alacsonyabb költséggel is megvalósítható légi támogatásra.

A kiírásban meghatározott legfontosabb követelmények egyúttal az úgynevezett alacsony intenzitású légi múveletek, illetve a gyenge légvédelemmel rendelkező ellenséges erők elleni légi müveletek jellemzőire is rávilágítanak:

- képes legyen gyengén kiépített vagy kiépítetlen ${ }^{12}$ repülőterekről történő rendszeres üzemelésre;

- fejlett önvédelmi rendszerekkel rendelkezzen, amelyek a modern légvédelmi eszközök ellen is hatékony védelmet nyújtanak, alacsony bevetési profilok esetén is;

- erős passzív védelemmel rendelkezzen, közöttük a létfontosságú részeket érintő páncélozással is;

- hosszú őrjáratozási idő jellemezze, lehetőleg 5 óra időtartamban;

- korszerü adatközlési képesség a létező hálózatokon keresztül;

- hírszerzési, megfigyelési és felderítési képesség (Intelligence, Surveillance, Reconnaissance, ISR);

LAS in, LAS out: Counter-insurgency planes for the USA and its allies. Defence Industry Daily, 2019. október 29.

Allen G. Peck: Airpower's crucial role in irregular warfare. Air and Space Power Journal, (2007), nyár. 10-11.

Robert F. Dorr: The LAAR lightweight combat aircraft is coming to the Air Force. Defense Media Network, 2010. január 25.

Az az időtartam, amíg a repülőeszköz a célterület felett (vagy annak közelében) tud tartózkodni fegyverterhelésétől, üzemanyagszintjétől és teljesítményétől függően. Minél hosszabb ez az idő, a repülőeszköz annál hosszabb ideig áll a földi csapatok rendelkezésére, támogatás céljából.

9 George H. Hock Jr.: Closing the irregular warfare air capability gap. Air and Space Power Journal, (2010), tél. 60-61.

10 A 2011-töl meghirdetett stratégiai irányváltás a korábbinál sokkal nagyobb diplomáciai, gazdasági, katonai figyelmet kívánt szentelni a régiónak az amerikai hozzáállásban.

11 Joshua Kurlantzick: The Pivot in Southeast Asia. Balancing interests and values. Council on Foreign Relations, 2015. január 08. 1-2.

12 Füves vagy köves repülőterek vagy leszállóhelyek, amelyek különösen jellemzőek voltak az afgán (és a harcok kezdeti szakaszában) az iraki hadszíntérre is. 
- nagy mennyiségü, külső felfüggesztésü fegyverzet; $;^{13}$

- alacsony üzemeltetési költségek: az elvárás szerint 1000 USD/repült óra az a szint, amelyet a hadszíntéren teljesítenie kellett ${ }^{14}$ a nyertes ajánlattevőnek. ${ }^{15}$

A következő lépés az úgynevezett részletes ajánlattételi felhívás (Request for Proposals, RFP) kiadása volt 2010 szeptemberében. Két vállalat nyújtott be pályázatot: az amerikai Beechcraft az AT-6B Wolferine típussal, illetve a brazil Embraer az A-29 Super Tucano típussal. $A$ végül rendkívül hosszúra nyúlt és hányattatott sorsú program egyik első problémás szakasza 2011-ben kezdődött a Beechcraft ajánlatának kizárásával technikai hiányosságokra és a feltételeknek való nem megfelelésre hivatkozva. ${ }^{16} 2011$ végén a USAF az Embraer ajánlatát hirdette ki győztesnek, azonban a Beechcraft többszöri fellebbezése egészen 2013-ig megakadályozta a szerződéskötést és a gyártás megkezdését. ${ }^{17}$ Mindkét oldal részéről komoly politikai lobbitevékenység zajlott (nem függetlenül a Beechcraft amerikai munkahelyeket jelentő Államokbéli gyártósorai okán) a Kongresszusban, amely sokáig teljesen ellehetetlenítette a szerződés teljesítését. ${ }^{18}$ Időközben az eredeti LAAR program neve is megváltozott, immár Könnyü Légi Támogatás (Light Air Support, LAS) ${ }^{19}$ névre hallgatott.

Az elhúzódó program következő állomását a USAF 2016-os újabb döntése jelentette, amikor az úgynevezett OA-X program keretében négy iparági szereplőt kért fel, hogy már kész, kipróbált, alacsonyabb költségű típusukkal ${ }^{20}$ bizonyítsák megfelelőségüket kedvezőtlen körülmények közötti bevetések esetén is. Erre a felhívásra összesen négy pályázó jelentkezett: a Textron Aviaton a frissen kifejlesztett Scorpion sugárhajtású típussal, az Embraer/Sierra Nevada vállalat a már korábban is nyertes A-29-essel, az ekkorra már szintén a Textron által kínált AT-6B típus, valamint az $L 3$ vállalat a Longsword típussal. Utóbbi három géptípus turboprop kialakítású ${ }^{21}$ volt. A követelmények érdemben nem változtak a megelőző kiíráshoz képest (fejlett alacsony támadó és közeli légi támogató képesség, éjjel-nappali bevethetőség, szárazföldi konvoj kísérő képesség, gyors fordulékonyság), pusztán kiegészültek néhány olyan elemmel (még alacsonyabb egységár, kifejezetten kedvezőtlen időjárási körülmények közötti megbízható üzemelés, kompatibilitás az időközben fejlesztett elektronikai önvédelmi

13 USAF receives first funding for LAAR Aircraft Programme. Airforce technology, 2009. december 10.

14 John Antal: The Light Attack Aircraft challenge. Making close air support effective again. Military Technology, (2020), 7-8. 28-30.

15 Ez óriási megtakarítást jelentett volna a szuperszonikus gépek hasonló profilú bevetéseikor megszokott mintegy 30-40 000 USD/repült óra költséghez képest.

16 David Oliver: Light Air Support Mission Aircraft, Light Attack/ISR Aircraft Overview. Regional Overview: Middle East-IDEX Focus. Military Technology 2/2019, 33.

17 David Oliver: Light Air Support Mission Aircraft, Light Attack/ISR Aircraft Overview. Regional Overview: Middle East-IDEX Focus. Military Technology 2/2019, 32.

18 A program ezen szakaszát a Szövetségi Fellebbviteli Bíróság döntése zárta le, amely jóváhagyta az A-29-es gyártását.

19 A program a fejlesztési folyamaton túl egy csatornát is jelentett, amelyen keresztül olyan szövetséges államoknak nyújthattak segítséget, amelyek komoly aszimmetrikus kihívásokkal küzdenek (például A-29-es gépeket kapott az Afgán Légierö [AAF], valamint Libanon is).

20 Az úgynevezett off-the-shelf megoldás lényege, hogy már létező technológiákkal, illetve típusokkal, esetlegesen kisebb mértékủ módosításokkal, jóval kedvezőbb beszerzési költséggel és jóval rövidebb idő alatt lehessen rendszeresíteni a kívánt típust.

21 Légcsavaros gázturbinás meghajtású típusok, amelyek üzemeltetési költsége jellemzően nagyságrendekkel alacsonyabb a sugárhajtású típusokénál. 
eszközökkel és digitális kommunikációs képesség a légierő más egységeivel), amelyek az újabb hadműveleti tapasztalatok okán váltak szükségessé. ${ }^{22} 2018$ februárjában aztán a légierő döntéshozói meglepő módon nem egy "szokásos" döntést hoztak a két tagúra szúkített pályázói mezőnnyel kapcsolatban, ugyanis nem a korábban tervezett harci demonstráció keretében terveztek dönteni a győztesről, hanem tovább dolgoztak mindkét vállalattal annak érdekében, hogy a lehető legtökéletesebb megoldást adó pályázó tudjon nyerni a későbbiekben. Ezt a tesztelési folyamatot zavarta meg egy baleset 2018 júniusában, amelynek során egy A-29-es került veszteséglistára. A programot azonnal felfüggesztették, és az újraindítást követően is lassabbá vált annak elörehaladása, bár a célja nem változott. ${ }^{23}$

2019 tavaszán a légierő sokadik nekifutásra tette le újra a voksát a könnyü támadó repülőgép mellett, igaz ismételten a korábbiaktól eltérő követelmények és keretrendszer feltételei között. A korábbi jelentős gépmennyiség helyett a két pályázótól már szerényebb gépmennyiségre kértek ajánlatot, amely gépek fö feladata immár kifejezetten az aszimmetrikus fenyegetést jelentő ellenséges erők elleni küzdelem, viszont kisebb arányban amerikai erők kötelékében, nagyobb arányban pedig a szövetséges légierők állományában. ${ }^{24}$ Az elképzelés szerint a Különleges Erők Parancsnoksága (Air Force Special Operations Command, AFSOC) venné átmeneti állományba az A-29-es gépeket tesztelés, fejlesztés céljából a floridai Hurlburt Field bázison - amelyeket a szövetséges haderők tagjait későbbiekben oktató úgynevezett harci repülési tanácsadók használnának (a program szerint ez a fajta oktató tevékenység egészen 2024-ig folytatódik az A-29-es gépekkel) ${ }^{25}$-, míg a Légiharc Parancsnokság (Air Combat Command, ACC) ugyanezt tenné az AT-6-osokkal a nevadai Nellis légibázison települve - amelyek feladata a későbbiekben a szövetséges haderők számára olcsón üzemeltethető, kommunikációs és felderítő platform biztosítása a koalíciós múveletek során ${ }^{26}$-, ezzel mindkét típusnak esélyt teremtve a fejlesztésre és a végső győzelemre. ${ }^{27}$ Ahogy David L. Goldfein tábornok, a USAF akkori vezérkari fönöke fogalmazott: „Arra fókuszálunk, hogy egy könnyü támadó repülőgép hogyan tudja segíteni szövetségeseinket és partnereinket az erőszakos szélsőségesség elleni küzdelmükben saját határaikon belül." ${ }^{28} \mathrm{~A}$ meglehetősen érdekes megoldás nem talált egyöntetű támogatásra szakmai körökben, ennek ellenére ennek szellemében került kiírásra az újabb részletes ajánlattételi felhívás, majd pedig a szükséges költségvetési háttér biztosításához a 2020-as védelmi költségvetésben is módosításokat eszközöltek. ${ }^{29} \mathrm{~A}$ program célja immár az úgynevezett Fegyveres Ellenörzés (Armed Overwatch) kezdeményezés keretében a speciális erők aszimmetrikus hadviselési képességeinek

22 Air Force search for new Light Attack Aircraft may begin by Spring. National Defense Blog, 2017. február 04.

23 Vivienne Machi: Air Force light attack vision inches closer to reality. National Defence, 2018. szeptember 27. 35-36.

24 Frank Wolfe: Defense authorizers push for ramp up of Light Attack Aircraft for SOF. Aviation Today, 2019. november 27.

25 Mark Ayton: Wichita's gutsy little striker. In United States Air Force air power yearbook 2021, Stamford, Key Publishing Ltd., 2020, 10-13.

26 Ehhez a tervek szerint az új verziónak (AT-6E) 2021 első félévében repülnie kell.

27 Joseph Trevithick: USAF may launch new Light Attack Aircraft tests to explore a requirement it already has. The Drive, 2019. november 13.

28 U.S. Air Force: Secretary of the Air Force Public Affairs: Air Force requests proposals for light attack aircraft. 2019. október 25.

29 Valeria Insinna: Sorry, Sierra Nevada Corp. and Textron: The US Air Force isn't buying light attack aircraft planes. Defense News, 2020. február 10. 
kiegészítése. A programot ismételten komoly kritikák érték, hiszen ekkorra már egy évtizednyi tesztelés, pályáztatás telt el eredménytelenül, ráadásul a légierő szinte ugyanazokat a pályázókat kérte fel újfent, amelyek korábban is pályáztak (némelyik ráadásul eredményesen). A döntés ráadásul a várható megrendelések számát is igen drasztikusan érintette, a korábbi mintegy 360 db-os megrendelés helyett mindössze néhány tucatra lesz szüksége a légierőnek ${ }^{30}$ (természetesen nem számítva az esetleges közvetlen külföldi megrendeléseket a szövetséges légierők részéről). Emellett a speciális erők képviselői is komoly kritikát fogalmaztak meg a program késedelmes megvalósítása kapcsán, mivel a több országban is aktív különleges műveletek során továbbra is sürgető igény mutatkozna a közeli légi támogatási képesség iránt. ${ }^{31}$ Egy lassan és alacsonyan támadni képes, sérülésálló sárkányszerkezettel rendelkező repülőgép, hosszú őrjáratozási idővel lenne a tökéletes légi támogató elem az ilyen műveleteket végrehajtó földi csapatoknak világszerte. ${ }^{32}$

Ennek ismeretében (is) különösen meglepő döntés született 2020 év elején, mégpedig a Könnyű Támadó Program törléséröl. Ennek ellenére néhány példányt tovább tesztel a légierő a jövőben, elsősorban új harceljárások és technológiák kifejlesztése céljából, de ez a jelenlegi álláspont szerint nem jelenti jelentősebb gépmennyiség megvásárlását a későbbiekben. ${ }^{33} \mathrm{~A}$ program a szövetséges légierők megerősítését célozza, könnyű támadó és felderítőgépekkel. Ennek keretében az AT-6-os többek között az új adatmegosztó hálózat ${ }^{34}$ tesztelésére is szolgál. Az A-29-es pedig a külföldi haderők pilóta és harckiképzését folytatja, amely a speciális erők terrorellenes múveleteit támogatná akár az amerikai légi haderőnem kötelékében, akár valamely külföldi légierő állományában. ${ }^{35}$ Ennek alapja az Afgán Légierő esetében például már 2016 óta létezik, abban az évben szállították le ugyanis az A-29-es típus első példányát. A fegyveres felkelés elleni küzdelemben már ekkor megkezdődött az afgán fél részvételi arányának növelése, amelyben kiemelt szerepet szántak a légierőnek. ${ }^{36}$ Mindez egy nagyon szoros koalíciós tanácsadói tevékenységgel történik, ebben a rendszerben sajátítanák el az afgán pilóták a földi támadó, azon belül is a közeli légi támogató tevékenységhez szükséges készségeket. ${ }^{37}$

A Fegyveres Ellenőrzés program pedig - bár módosításokkal - folytatódik, részben azonos szereplőkkel, hiszen a két fenti gyártó mellett benyújtotta pályázatát az L3 Technologies, az Air Tractor és a Leidos is. E program jelenleg egy viszonylag egyszerű célkitűzéssel rendelkezik: megfelelö, egyszerủ és gyorsan hadrendbe állítható platformot találni a különleges erők közeli légi támogató repülőgépének szerepkörébe,

30 Jeremiah Gertler: Air Force OA-X Light Attack Aircraft Program. Congressional Research Service, In Focus, 2021. március 30. 1-2.

31 Michael Waltz: The case for light-attack aircraft. Military Times, 2019. október 29.

32 Trevithick (2019) i. m.

33 Insinna (2020) i. m.

34 Az AEROnet névre hallgató adatátviteli és kommunikációs rendszer egy sokkal hatékonyabb video-, hang-, szöveges üzenetközlésre, valamint adatcsomagok átvitelére szolgáló rendszer lesz, amelyet a szövetséges haderők is használhatnak a tervek szerint. Rendszerbe állításának várható ideje 2022 májusa.

35 Rachel S. Cohen: USAF issues seeed money for four light-attack aircraft. Air Force Magazine, 2020a. március 17.

36 A típus meglehetősen sikeres e szerepkörben. 2020 őszéig mintegy 311 sikeres légicsapást hajtott végre az Afgán Légierő, és ezen időszak alatt nem érkezett független jelentés civil áldozatokról. Ez azt is jelezheti, hogy a könnyủ támadó repülőgép fejlesztési modell alapvetően helyes elképzelés volt.

37 Rachel S. Cohen: Light attack providers get second shot with SOCOM. Air Force Magazine, 2020b. május 13. 
amelyek állandó jelleggel ezen alakulatok rendelkezésére állnának, így nem szükséges értékes repült időt elvonni egyéb, konvencionális műveletektől. ${ }^{38} \mathrm{~A}$ program keretében a tervek szerint összesen 75 db repülőgépet kívánnak rendszerbe állítani, 7 éves időintervallumon belül. ${ }^{39}$ Az ütemezés szerint a kiválasztás és a tesztelés 2021 első felében befejeződik, és a prototípus már ez év nyarán a levegőbe emelkedhet.

\section{Az aszimmetrikus kihívások hatása a programra - elméleti háttér}

Az utóbbi két évtized több amerikai vagy NATO vezetésű légi hadműveletében kiemelt szerepet kaptak az aszimmetrikus hadviselés követelményei, illetve az ezek jelentette kihívások a részt vevő légierők számára. Az első állomás e folyamatban egyértelmüen az Afganisztán elleni 2001-es amerikai hadmüvelet volt, illetve még inkább a gyors katonai győzelmet követő pacifikálási folyamat, ${ }^{40}$ a majdnem két évtizede húzódó felkelésellenes müveletek a Talibán ellen. Ez a háború mutatta meg igazán, hogy az amerikai légi haderőnem nem teljesen volt felkészülve egy ilyen jellegü, hosszan elhúzódó múveletre. Sem a rendelkezésre álló technika, sem az alkalmazott harceljárások nem feleltek meg az ellenfél jelentette kihívásoknak, éppen ezért már a müveletek kezdeti szakaszától kísérletek történtek az alkalmazkodásra, a folyamatos változtatásra. ${ }^{41}$ Mivel az ellenfél nem rendelkezett hagyományos értelemben vett katonai vezetési pontokkal, a légierő által biztosított aszimmetrikus képességek közül (ISR-képességek, precíziós légicsapások, saját erők gyors telepítése és kivonása) az ISR-képességek és az időben pontos, precíziós légicsapások képessége gyengén védett célpontok (jellemzően személyek, lakóházak, kisebb létesítmények) ellen ${ }^{42}$ vált kulcsfontosságúvá. ${ }^{43}$ A 2003-as Irak elleni inváziót követően e müveletek megsokszorozódtak, és az összes légierős bevetés jelentős részét tették ki a közeli légi támogató bevetések. A saját vagy szövetséges erők elleni közeli légicsapások komoly technológiai szintet és a célterület feletti folyamatos jelenlétet követeltek meg, amelyeket a hadmüveletek előrehaladtával egyre nagyobb hatékonysággal volt képes ellátni a USAF. ${ }^{44}$ Ennek rendkívül magas költségigénye volt, és óriási mértékben leterhelte az eredetileg más célokra szánt gépállományt is. ${ }^{45}$

38 Garrett Reim: US Special Operations plans to buy 75 light attack aircraft for Armed Overwatch. Fligh Global, 2020a. február 15.

39 Reim, Garrett: US Air Force adds two AT-6 light attack aircraft to continued experiment. Fligh Global, 2020b. március 16.

40 Bernie Willie: The importance of air power in supporting irregular warfare in Afghanistan. Air and Space Power Journal, (2012), július-augusztus. 114-115.

41 Jon C. Wilkinson - Andrew Hill: Airpower against the Taliban. Systems of denial. Air and Space Power Journal, (2017), ösz. 53-56.

42 Géraud Laborie: The Afghan model more than 10 years later. An undiminished relevance, ASPJ Africa and Francophonie, (2013), 3rd Quarter. 58-59.

43 Will Selber: The other side of the COIN. Air and Space Power Journal, (2018), ősz. 81.

44 Selber (2018) i. m. 73-74.

45 Például a légierő F-15-ös típusának várható élettartama jelentősen csökkent a rendkívüli műveleti leterheltség okán (hasonlóan a Haditengerészet F-18-as vadászbombázóihoz). 
Az Iszlám Állam (ISIS) elleni hadműveletek ismételten rávilágítottak ezen képességek fontosságára, még az utóbbi évek folyamatos ilyen irányú fejlesztései mellett is. Az iszlamista terrorszervezet meglehetősen összetett kihívást jelentett az ellene harcoló nemzetközi koalíció légierői számára, lévén egyszerre többféle ellenség jellemzőivel ${ }^{46}$ is rendelkezett, így az alkalmazott eljárások is többfélék voltak a müveletek során. A hagyományos légi háború elméletek közül több is értelmezhető volt e műveletekben. Warden ${ }^{47}$ és Pape elméletei egyaránt alkalmazhatóak voltak az ISIS elleni aszimmetrikus hadviselésre. Warden 5 gyürü modellje ${ }^{48}$ értelmében kísérletek történtek az ellenséges célpontok többféle rétegének (vezetői réteg, elfoglalt infrastruktúra) elleni támadására, így végső soron a cél az ellenség stratégiai megbénítása volt. ${ }^{49}$ Pape gondolatai jegyében pedig, mivel az ISIS nem támaszkodott klasszikus értelemben a logisztikára, utánpótlási vonalakra, sokkal több eredményt lehetett elérni a közeli légi támogatás eszközével (Close Air Support, CAS), amely az aszimmetrikus fenyegetések esetén az egyik leggyakrabban alkalmazott légi müvelettípus..$^{50} \mathrm{Az}$ ISIS elleni múveletek végső sikere a szakértők szerint nagymértékben volt köszönhető a légi támogatás hatékonyságának, elsősorban a közeli légi támogatás pontosságának és összehangoltságának a szárazföldön elörenyomuló szövetséges csapatok műveleteivel. Mindezt persze a részt vevő légierők kiemelkedő technológiai színvonalat képviselő repülőgépeinek magas intenzitású bevetéseivel sikerült megvalósítani, ez pedig igen költségigényes. A szövetséges géptípusok minden esetben legalább 4. generációs szintet képviselő eszközök voltak, amelyeknek repült órái komoly költséget jelentettek, nem beszélve a repülőgépek úgynevezett gyári élettartamának ${ }^{51}$ nagymértékü kihasználásáról. Bár az iraki és szír hadszíntéren végrehajtott bevetések bonyolultabb környezetben valósultak meg, mint az afgán légi müveletek, de egy jelentős részük szintén végrehajtható lett volna egyszerủbb és specifikusan szárazföldi célpontok elleni támadások végrehajtására optimalizált géptípusokkal, sokkal költséghatékonyabban. Mivel a fentiekben jelzett nagy intenzitású, időben pontos légicsapások egyik alapfeltétele a hosszú célterület feletti őrjáratozás volt, ez a részt vevő géptípusok jellegéből adódóan ${ }^{52}$ pedig rendkívül magas költséget jelentett. ${ }^{53} \mathrm{~A}$ korábbi fejezetekben tárgyalt specifikus, könnyű támogató repülőgéptípusok nagy valószínűséggel sokkal olcsóbban tudták volna végrehajtani az ISIS elleni műveleteket, különösen ha kisebb egy repült

46 Tekintettel a szervezetben szerepet vállalt regurális katonákra (föként a korábbi iraki haderőben szolgáló, akár magas rangú tisztekre), a számos országból érkező önkéntes, irreguláris jellegű csapatokra, valamint a rövid idő alatt elfoglalt nagy földrajzi kiterjedésü területekre, az alkalmazott harceljárások is egyfajta elegyét alkották a regurális és irreguláris hadviselésnek.

47 Robert Pape úgynevezett kényszerítés elmélete szerint az ellenség a már elszenvedett veszteségektől való félelem okán tartózkodik a további tevékenységtől.

48 John Warden 5 gyürüs elmélete szerint megkülönböztethetünk különböző szinteket az ellenség célpontjai között, amelyek légi támadása eltérő eszközöket követel meg, és eltérő eredményeket is hoz.

49 Valéria de Moura Sousa - Augusto W.M. Teixeira Júnior: Airpower and counterinsurgency. The strategic logic of Operation Inherent Resolve. Journal of the Americas, (2020), First edition. 196-197.

50 Moura Sousa - Teixeira (2020) i. m. 197-199.

51 Az az általában naptári évben vagy repült órában megadott érték, amelyet a gyártó eredetileg meghatározott mint maximális élettartamot (létezik külön adat a sárkányszerkezetre, a hajtómüre stb. vonatkozóan).

52 A USAF részéről elsősorban F-16-os, F-15-ös vadászbombázók, A-10-es csatarepülőgépek, F-22-es vadászgépek, amelyek nagy harcértékü, de drágán üzemeltethető típusok, amelyeket eredetileg komoly eszközökkel, integrált légvédelemmel rendelkező, fejlett ellenfelek elleni bevetésekre terveztek.

53 Moura Sousa - Teixeira (2020) i. m. 208. 
órára eső üzemeltetési költségeiket ${ }^{54}$ és sokkal nagyobb célterület feletti őrjáratozási idejüket vesszük figyelembe. ${ }^{55}$

Mindezen tapasztalatokból fakadó igényeket azonban nem volt egyszerü kielégíteni, lévén, az amerikai légi haderőnem története során igazán soha nem kötelezte el magát az egyszerübb technológiai színvonalat képviselő, igazán többfeladatú, földi csapatokat támogató típusok mellett. A több mint 60 éves doktrínát - miszerint a légierő feladata egy erős, felkészült ellenféllel szemben kivívni a győzelmet a lehető legmagasabb technológiai szintet képviselő géptípusokkal - természetesen nem egyszerü felülírni. Az afganisztáni és iraki hadszíntéren is több év telt el, mire elkezdődött a lehetséges és szóba jöhető könnyű támadó típusok kiválasztását célzó program. Mint fentebb láthattuk, erre egészen 2009-ig kellett várni. ${ }^{56}$ Emellett arról sem szabad megfeledkezni, hogy az új müveleti igények jelentette kihívásokat úgy kellett megválaszolni, hogy közben a légierő hagyományos szerepköre és céljai sem tűntek el, sőt új katonai nagyhatalmak egyre erősödő befolyása okán bizonyos területeken viszonylag gyors válaszokra lett volna szükség (például a kínai és orosz hiperszonikus fegyverek elleni védekezés). Tehát egyszerre kellett volna egy merőben új képességbeli hiányosságot (könnyü támadó képesség) gyorsan, hatékonyan pótolni és a régi, konvencionális képességeket is fejleszteni, de legalábbis szinten tartani. Mindezt 2008-tól kezdődően egy alapvetően megszorító védelmi költségvetési környezetben. A 2010-es évek elején több érdekes javaslat is született az afgán és iraki hadszíntéren folyó események javítása érdekében: ilyen volt, hogy egy külön speciális szervezeti egységet kellene létrehozni a légierő vezetésén belül, amely dedikáltan a felkelésellenes müveletek légi támogató elemeit koordinálja és hajtja végre; a másik javaslat arra irányult, hogy a helyi afgán nemzeti légierőt vonják be sokkal nagyobb mértékben a földi csapatokat támogató müveletekbe, ${ }^{57}$ minél több repülőeszközt rendelkezésükre bocsátva, és a korszerü harceljárások elsajátítását segítve. ${ }^{58}$

Súlyos problémát jelentett emellett a koalíciós légicsapások pontosságának kérdése is. A szuperszonikus vadászbombázó típusok és a bevetett fegyverek találati pontossága rengeteget fejlődött az afgán és az iraki, különösen pedig az ISIS elleni légi bevetések során, de sajnos továbbra is előfordultak baráti tüzben történt saját vagy szövetséges veszteségek és civil áldozatok is. Ennek kiküszöbölésére folyamatosan történtek technológiai fejlesztések (elsősorban a célmegjelölés, valamint az alkalmazott fegyverek terén), de újabb minőségi ugrást szintén egy könnyű támadó típus alkalmazása jelentett volna, amely alacsonyabb magasságon, hosszabb időt a célterület felett töltve (ezzel több időt biztosítva a pilóta vagy a földön tevékenykedő úgynevezett elöretolt repülésirányító tiszt [Joint Terminal Attack Controller, JTAC, aki

54 Trevor Phillips-Levine: Redistributing airpower for the spectrum of warfare. Air and Space Power Journal, (2020), ösz. 65.

55 Phillips-Levine (2020) i. m. 61-63.

56 A hivatalos LAAR program megindítását megelőzően mindössze átmeneti, időszakos megoldásokat kerestek a probléma megoldására (nem katonai célokra készült gépek átalakítása, illetve a különböző 4. generációs vadászbombázók szoftveres és hardveres „kiegészítése”, célzott képességfejlesztése).

57 Phillips-Levine (2020) i. m. 66-67.

58 Utóbbi javaslat részben megvalósult, hiszen az Afgán Légierő merev- és forgószárnyas egységeit is jelentősen megerősítették az évek alatt, folyamatosan új eszközöket és tudást biztosítva részükre (e folyamatban például a Magyar Légierő helikopteres oktatói is tevékenyen részt vettek több éven keresztül), illetve a könnyü támadó repülőgép program jelenlegi formájában (Armed Overwatch) is a szövetséges Afgán Légierőre kíván nagyobb felelősséget osztani e szerepkörben. 
a földi csapatok közeli légi támogatását koordinálja a térségben tevékenykedő légi egységekkel történő kommunikáció és célravezetés útján] számára a hatékony célmegjelölésre) tud légi támogatást nyújtani. Természetesen még ez sem tudta volna teljesen megszüntetni a civil áldozatok valószínüségét, mivel szakértők szerint azt az ellenfél alapvető stratégiája (miszerint tevékenysége nagy részét a civil lakosság között elvegyülve, de legalábbis közvetlen közelükben fejti ki) okozta. ${ }^{59}$

\section{A jövő - az aszimmetrikus képességek háttérbe szorulása?}

Az LAAR, LAS, OA-X programok fentiekben jelzett módon történt lezárása természetesen rengeteg szakmai, politikai, gazdasági kritikát hívott életre a teljes programmal szemben, ${ }^{60}$ illetve a USAF prioritásai kapcsán is. ${ }^{61}$ Mint ahogyan azt a fenti fejezetekben láthattuk, az elmúlt időszak aszimmetrikus müveleti igényei számos fejlesztést életre hívtak a légierő könnyű támadó, közeli légi támogató szerepkörben dolgozó egységei tekintetében, de már az afganisztáni és iraki harcok idején felmerült a kérdés, hogy a valóban létfontosságú képességet vajon milyen hatásfokkal tudná használni a légi haderőnem egy jobban felszerelt, erős légvédelemmel rendelkező ellenféllel szemben? Erre a célra egyes tervezők a régi A-10-es csatarepülőgépet tartják a legalkalmasabbnak, ${ }^{62}$ amely már számos konfliktusban bizonyította képességeit, azonban egy erős légvédelemmel, esetleg fejlett úgynevezett hozzáférést korlátozó/megtagadó (Area Access/Area Denial, A2/AD-) eszközökkel felszerelt hadszíntéren valószínüleg már csak jelentős veszteségekkel tudná ellátni feladatait. ${ }^{63}$ Emiatt a légierő az új 5 . generációs F-35-ös vadászbombázó mellett tenné le voksát egy jövőbeli konfliktus földi támogató szerepkörében is. ${ }^{64}$

Az egyes speciális szerepköri kérdéseken túl az az általános kérdés is felmerül az amerikai védelmi tervezők körében, hogy a jelenkori új irányok - például a csendes-óceáni régió elsőbbsége a jövőbeli prioritásokat illetően - mennyiben jelentenek trendváltást az aszimmetrikus képességek fejlesztése irányából a konvencionális, hagyományos légi képességek fejlesztésének irányában. Az afganisztáni, az iraki, a líbiai, az ISIS vagy éppen a Boko Haram elleni hadműveletek során minden esetben a légierő volt az első, amelyet a politikai vezetés bevetett mint a leggyorsabban mozgósítható haderőnemet, amely hatékonyan alkalmazható valamennyi fenyegetéssel szemben. Ezen esetekben szinte mindig gyenge államok vagy éppen nem állami szereplők ellen kellett bevetni a légi haderőnemet, amely jelenség a stratégiai tervezők szerint várhatóan középtávon is fennmarad. Mindez azzal is jár, hogy a légierőnek a már megszokott

\footnotetext{
Moura Sousa - Teixeira (2020) i. m. 205-208.

Phillips-Levine (2020) i. m. 65.

61 Az amerikai Mitchell Institute például 2018-as jelentésében a könnyủ támadó repülőgép program keretében kiválasztott mindkét típust kiválónak minősítette, amelyek tökéletesen alkalmasak lennének a különböző hadszíntereken harcoló alakulatok azonnali megsegítésére.

62 Az A-10-es géphez kapcsolódó igen ambivalens szakmai és politikai hozzáállás történetét jelen tanulmányban terjedelmi okok miatt nem célom kifejteni.

63 Steven Fino: The coming close air support fly-off. Lessons from AIMVAL-ACEVAL. Air and Space Power Journal, (2017), nyár. 17-18.

64 Phillips-Levine (2020) i. m. 61-63.
} 
rugalmasságával lesz szükséges reagálnia a jövőben is az egymástól akár földrajzilag is nagy távolságokon felmerülö, adott esetben akár teljesen eltérő jellemzőkkel rendelkező aszimmetrikus fenyegetésekre. Ráadásul a CAS szerepkörben tevékenykedő repülőeszközökkel szemben újabb és újabb követelmények jelentkeznek, például az egyre fejlettebb szenzorrendszerek, megfigyelő eszközök vagy célmegjelölők szükségessége.

Emellett azonban fokozatosan fel kell készülnie az új, konvencionális feladatokra ${ }^{65}$ is, amelyeket a Kínához hasonló lehetséges ellenfelek hívnak életre. Ha közelebbről megvizsgáljuk a USAF jelenlegi doktrínáit, ${ }^{66}$ akkor fő feladatként továbbra is határozottan szerepelnek a következő feladatok és célkitűzések: megvédeni az amerikai érdekeket és a szövetségesek érdekeit fejlett haderővel rendelkező ellenfelekkel szemben; az ellenfél harcjármüveinek, létesítményeinek, vezetési pontjainak megsemmisítése. ${ }^{67}$ Megítélésem szerint érdekesség, hogy az Amerikai Légierő szinte semmilyen Afganisztánban és Irakban megszerzett pozitív vagy éppen negatív tapasztalatot nem emel át a hivatalos konvencionális hadviselési céljai közé, sokkal inkább egy „tiszta lappal" történő újraindítás történik. Ennek oka lehet, hogy a USAF mint szervezet folyamatosan igyekszik megfelelni a várható jövőbeli, sokkal inkább konvencionális kihívásoknak, így ezeket a képességeket hangsúlyozza a már „jól ismert”, elmúlt évtizedekben tökéletesített aszimmetrikus képességekkel szemben.

A 2020 év eleji döntés - miszerint eredmény nélkül megszüntetésre kerül a könynyű támadó repülőgép program, de szinte rögtön ezt követően megerősítésre került a Fegyveres Ellenőrzés keretében 75 ilyen típusú eszköz fejlesztése és beszerzése a különleges alakulatok és a szövetséges légierők számára ${ }^{68}$ - véleményem szerint tökéletesen mutatja ezt a kettősséget a légierő stratégái szempontjából. Az aszimmetrikus fenyegetések hatékony leküzdése, bár kisebb intenzitással, de továbbra is fontos célkitűzés, emellett pedig egy sor hagyományos képesség elérése, vagy újra elérése, is kiemelt prioritás. E két célt egyszerre elérni nem egyszerü feladat, különösen annak figyelembe vételével, hogy a költségvetési források sem állnak végtelen mennyiségben rendelkezésre. E kettősségből eredő ellentmondást egyes szakértők szerint azzal is fel lehetne oldani, ha a több évtizeden keresztül fejlesztett, tökéletesített könnyű támadó, illetve közeli légi támogató koncepciót valamilyen formában alkalmazni lehetne a jövő konvencionális összecsapásaiban is. Erre példaként a jelenleg rendelkezésre álló könnyű támadó gépek hosszú távú támadó fegyverekkel (például csapásmérő cirkálórakétákkal, nagy értékü célpontok elleni rakétafegyverekkel) történő felfegyverzését javasolják, amelyekkel ezek a típusok is eredményesen támadhatnának még jól védett, technikai eszközökkel jól ellátott úgynevezett közel azonos vagy azonos katonai technológiai szinten álló (neer-peer vagy peer) ellenfeleket is, hiszen a gépek egyes tulajdonságai (nagy őrjáratozási idő, alacsony magasságban végzett bevetések, alacsony sebesség) szerencsésen találkoznának más előnyös tényezőkkel (mint a többszörös hangsebességgel repülő rakétafegyverek előnyei). Ez úgynevezett

65 Ezek tulajdonképpen régi-új feladatok: erős légvédelmi rendszer áttörése, majd csapásmérés a kiemelt célpontokra, erős A2/AD-eszközökkel felszerelt területen történő hatékony manőverezés, illetve feladat-végrehajtás, saját erők bejuttatása és kivonása ezen területről, légi fölény kivívása és fenntartása.

66 A jelenleg érvényes légi és földi ellenfelek elleni doktrínák (counterair operations és counterland operations) címü dokumentumok 2015-re, illetve 2019-re datálódnak.

67 Selber (2018) i. m. 81.

68 Patrick Tucker: Here's what special operators want from their new light attack plane. Defense One, 2020. december 12. 
high-low mix képességeket jelentene, vagyis a magas technológiai színvonal egyesülne az alacsonyabb technológiájú megoldásokkal, összességében előnyös tulajdonságokat létrehozva. ${ }^{69}$

Egy másik javaslat szerint a légierőnek a jövőben a konvencionális, hagyományos képességek nagyarányú fejlesztésére kellene koncentrálnia, míg a földi csapatok támogatásának feladatát át kellene adnia a hadsereg (Army) repülőalakulatainak. Ennek oka, hogy a hagyományosan alacsony intenzitásúnak számító terrorellenes műveletek esetén legtöbbször teljes légifölényt birtokol az amerikai vagy koalíciós légierő, ennélfogva a bevetett légi eszközökre nem jelentenek valós veszélyt a földön harcoló ellenfél alakulatai (ez alól a helikopterek képeznek bizonyos esetekben kivételt). Ennélfogva a földi csapatok hatékonyabban tudnák irányítani a számukra létfontosságú közeli légi támogatási műveleteket, mint teszi azt a légi haderőnem. A másik ok, hogy az alacsony intenzitású hadszíntereken folyó műveletek - bár nem olyan látványosan mutatják a légierő fontosságát - továbbra is kulcsfontosságúak maradnak az amerikai stratégiai elképzelések teljesítése szempontjából. Amennyiben a légierő a magasabb intenzitású hadszínterekre és a konvencionális képességekre fókuszálja fejlesztési erőforrásait, úgy azt a célt hatékonyabban lesz képes elérni, míg az aszimmetrikus képességeket a hadsereg tudná továbbfejleszteni, ezzel is tehermentesítve a légi haderőnemet a párhuzamos fejlesztési kényszer alól. Az ötlet képviselői szerint az elmúlt években közeli légi támogatásra használt szuperszonikus vadászgépek és vadászbombázók (F-15-ös, F-16-os, F/A-18-as) - sőt egyes esetekben még bombázó gépek is (B-52, B1-B) - bár sok fejlesztésen estek át (mind az alkalmazott harceljárásokat, mind a bevetett eszközök pontosságát illetően), továbbra is többletköltségeket és a flotta idő előtti „fáradtságát" okozzák, egész egyszerüen azért, mert eredetileg nem e szerepre szánták őket. Az új típusok pedig (mint az F-35-ös) bár korlátozottan képesek e feladat ellátására, fedélzeti eszközeik többsége nem erre lett optimalizálva. Az úgynevezett pilóta nélküli repülőeszközök szerepéról szintén vegyes megoldást javasol az elképzelés, mégpedig a földi támogató szerepkör megosztását ezen eszközök és a könnyű támadó repülőgépek között. A nagy értékủ és időérzékeny célpontok ellen használnák a különböző pilóta nélküli eszközöket (például MQ-9 Reaper), míg a "hagyományos” földi támogató szerepkörben a Fegyveres Ellenörzés program végső nyertesét. ${ }^{70} \mathrm{Az}$ ötlet vitán felüli legfontosabb pozitívuma véleményem szerint a specializáció és a képességbeli párhuzamosságok csökkentése lenne. Természetesen egy ilyen elképzelés fogadtatása az haderőnemek vezetői részéről legalábbis kétséges, tekintve a már hagyományosnak mondható versengést az egyes feladatkörökért.

A könnyü támadó repülőgépek lehetséges jövőbeli szerepkörét illetően szintén felmerül a megfelelő doktrína hiánya, ugyanis dacára az elmúlt két évtized kiterjedt aszimmetrikus légi hadviselésének, igazán testre szabott doktrínával nem rendelkezik a USAF e téren. Ennek pótlása alapvető fontosságú lehet egy jövőbeni, vegyes feladatellátás során, hiszen egy viszonylag korlátozott számú, de jól szervezett, világos célokkal rendelkező könnyű támadó repülőgépflotta igen jól kiegészítheti a magas intenzitású ellenfelekkel küzdő légierő nagyobb részét. ${ }^{71}$

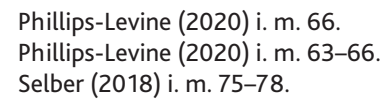




\section{Következtetések}

Írásomban röviden ismertettem az Amerikai Légierő egy hosszú időn át húzódó beszerzési programját, amely az utóbbi évtizedek meghatározó feladatának, az aszimmetrikus légi hadviselés, a terrorizmus elleni küzdelem légi eleme által támasztott követelményeknek kívánt eleget tenni. A program hányatott sorsa, rendkívül hosszú kifutási ideje, az időközben többször és jelentős mértékben megváltozott követelményrendszer és nem utolsósorban annak felemás végeredménye megmutatták, hogy milyen nehézségeket okoz az egymástól merőben eltérő elvárásoknak (aszimmetrikus és konvencionális) történő megfelelni akarás még egy olyan méretű és műveleti tapasztalatokkal rendelkező szervezet esetében is, mint a légierő. Előzetesen megfogalmazott feltevésemet, miszerint a konvencionális képességekre történő felkészülés prioritást élvez-e az Amerikai Légierő tervei között, a vizsgált beszerzési program példáján keresztül nem lehetett kétséget kizáróan megerősíteni, ugyanis a konvencionális képességek egyértelmü túlsúlya ellenére az aszimmetrikus képességek továbbra is szerepelnek a jövőbeni célkitűzések között. A jelek szerint - ha csak a jelenlegi műveletek jelentette kényszer hatására is, de - az alacsony intenzitású légi hadmúveletek és ezekhez szükséges képességek továbbra is jelen lesznek, így a védelmi tervezőknek egyfajta vegyes modellt szükséges kialakítaniuk a megfelelő felkészültségi szint fenntartásához.

\section{Felhasznált irodalom}

Air Force search for new Light Attack Aircraft may begin by Spring. National Defense Blog, 2017. február 04.

Antal, John: The Light Attack Aircraft challenge. Making close air support effective again. Military Technology, (2020), 7-8. 28-31. Online: www.monch.com/mpg/ ebooks/military-technology/2020/07hgr2wcm/32/

Ayton, Mark: Wichita's gutsy little striker. In United States Air Force air power yearbook 2021. Stamford, Key Publishing Ltd., 2020.

Cohen, Rachel S.: Light attack providers get second shot with SOCOM. Air Force Magazine, 2020b. május 13. Online: www.airforcemag.com/light-attack-providers-get-second-shot-with-socom/

Cohen, Rachel S.: USAF issues seeed money for four light-attack aircraft. Air Force Magazine, 2020a. március 17. Online: www.airforcemag.com/usaf-issues-seedmoney-for-four-light-attack-aircraft/

Dorr, Robert F.: The LAAR lightweight Combat aircraft is coming to the Air Force. Defense Media Network, 2010. január 25. Online: www.defensemedianetwork. $\mathrm{com} / \mathrm{stories/the-laar-lightweight-combat-aircraft-is-coming-to-the-air-force/}$

Fino, Steven: The coming close air support fly-off. Lessons from AIMVAL-ACEVAL. Air and Space Power Journal, (2017), nyár. 17-38. Online: www.airuniversity.af.edu/ Portals/10/ASPJ/journals/Volume-31_Issue-2/F-Fino.pdf

Gertler, Jeremiah: Air Force OA-X Light Attack Aircraft Program. Congressional Research Service, In Focus, 2021. március 30. Online: https://fas.org/sgp/crs/ weapons/IF10954.pdf 
Hock Jr., George H.: Closing the irregular warfare air capability gap. Air and Space Power Journal, (2010), tél. 56-68. Online: https://apps.dtic.mil/sti/pdfs/ADA533561.pdf

Insinna, Valeria: Sorry, Sierra Nevada Corp. and Textron: The US Air Force isn't buying light attack aircraft planes. Defense News, 2020. február 10. Online: www. defensenews.com/smr/federal-budget/2020/02/10/sorry-sierra-nevada-corpand-textron-the-us-air-force-isnt-buying-light-attack-planes/

Krajnc Zoltán: Az aszimmetrikus hadviselés, fenyegetés alapkérdései. Repüléstudományi konferencia, 2008. április 11. Online: http://epa.oszk.hu/02600/02694/00044/ pdf/EPA02694_rtk_2008_01_Krajnc_Zoltan.pdf

Kurlantzick, Joshua: The Pivot in Southeast Asia. Balancing interests and values. Council on Foreign Relations, 2015. január 08. Online: www.cfr.org/report/pivotsoutheast-asia

Laborie, Géraud: The Afghan model more than 10 years later. An undiminished relevance. ASPJ Africa and Francophonie, (2013), 3rd Quarter. 49-60. Online: www. airuniversity.af.edu/Portals/10/ASPJ_French/journals_E/Volume-04_Issue-3/ Laborie_e.pdf

LAS in, LAS out: Counter-insurgency planes for the USA and its allies. Defence Industry Daily, 2019. október 29. Online: www.defenseindustrydaily.com/las-in-las-outcounter-insurgency-planes-for-the-usa-and-its-allies-010548/

Machi, Vivienne: Air Force light attack vision inches closer to reality. National Defence, 2018. szeptember 27. Online: www.nationaldefensemagazine.org/ articles/2018/8/27/air-force-light-attack-vision-inches-closer-to-reality

Moura Sousa, Valéria de - Augusto W.M. Teixeira Júnior: Airpower and counterinsurgency. The strategic logic of Operation Inherent Resolve. Journal of the Americas, (2020), First edition. 196-211. Online: www.airuniversity.af.edu/Portals/10/JOTA/ Journals/Volume\%202\%20Issue\%201/04-Moura\%20Teixeira_eng.pdf

Oliver, David: Light Air Support Mission Aircraft, Light Attack/ISR Aircraft Overview, In: Regional Overview: Middle East - IDEX Focus. Military Technology 2/2019.

Peck, Allen G.: Airpower's crucial role in irregular warfare. Air and Space Power Journal, (2007), nyár. 10-16. Online: www.airuniversity.af.edu/Portals/10/ASPJ/journals/ Volume-21_Issue-1-4/2007_Vol21_No2.pdf

Phillips-Levine, Trevor: Redistributing airpower for the spectrum of warfare. Air and Space Power Journal, (2020), ösz. 54-69. Online: www.airuniversity.af.edu/ Portals/10/ASPJ/journals/Volume-34_Issue-3/V-Phillips_Levine.pdf

Reim, Garrett: US Air Force adds two AT- 6 light attack aircraft to continued experiment. Fligh Global, 2020b. március 16. Online: www.flightglobal.com/fixed-wing/us-airforce-adds-two-at-6-light-attack-aircraft-to-continued-experiment/137318.article

Reim, Garrett: US Special Operations plans to buy 75 light attack aircraft for Armed Overwatch. Fligh Global, 2020a. február 15. Online: www.flightglobal.com/ fixed-wing/us-special-operations-plans-to-buy-75-light-attack-aircraft-for-armed-overwatch/136560.article

Resperger István - Kiss Álmos Péter - Somkuti Bálint: Aszimmetrikus hadviselés a modern korban. Kis háborúk nagy hatással. Budapest, Zrínyi, 2015. 
Selber, Will: The other side of the COIN. Air and Space Power Journal, (2018), ösz. 72-84. Online: www.airuniversity.af.edu/Portals/10/ASPJ/journals/Volume-32 Issue-3/V-Selber.pdf

Trevithick, Joseph: USAF may launch new Light Attack Aircraft tests to explore a requirement it already has. The Drive, 2019. november 13. Online: www.thedrive.com/ the-war-zone/31002/usaf-may-launch-new-light-attack-aircraft-tests-to-explore-a-requirement-it-already-has

Tucker, Patrick: Here's what special operators want from their new light attack plane. Defense One, 2020. december 12. Online: www.defenseone.com/technology/2020/02/heres-what-special-operators-want-their-new-light-attackplane/163088/

USAF receives first funding for LAAR Aircraft Programme. Airforce technology, 2009. december 10. Online: www.airforce-technology.com/news/news72193.html

U.S. Air Force: Secretary of the Air Force Public Affairs: Air Force requests proposals for light attack aircraft. 2019. október 25. Online: www.af.mil/News/Article-Display/ Article/1998584/air-force-requests-proposals-for-light-attack-aircraft/

Waltz, Michael: The case for light-attack aircraft. Military Times, 2019. október 29. Online: www.militarytimes.com/opinion/commentary/2019/10/29/thecase-for-light-attack-aircraft/

Wilkinson, Jon C. - Andrew Hill: Airpower against the Taliban. Systems of denial. Air and Space Power Journal, (2017), ősz. 44-59. Online: www.airuniversity.af.edu/ Portals/10/ASPJ_Spanish/Journals/Volume-30_Issue-1/2018_1_06_wilkinson_s_eng.pdf

Willie, Bernie: The importance of air power in supporting irregular warfare in Afghanistan. Air and Space Power Journal, (2012), július-augusztus. 103-117. Online: www. airuniversity.af.edu/Portals/10/ASPJ/journals/Volume-26_Issue-4/V-Willi.pdf

Wolfe, Frank: Defense authorizers push for ramp up of Light Attack Aircraft for SOF. Aviation Today, 2019. november 27. Online: www.aviationtoday.com/2019/11 /27/85707/ 